\title{
The subcommissural organ of the rat secretes Reissner's fiber glycoproteins and CSF-soluble proteins reaching the internal and external CSF compartments
}

\author{
Karin Vio, Sara Rodríguez, Carlos R Yulis, Cristian Oliver and \\ Esteban M Rodríguez*
}

Address: Instituto de Anatomía, Histología y Patología, Facultad de Medicina, Universidad Austral de Chile, Valdivia, Chile

Email: Karin Vio - karinvio@uach.cl; Sara Rodríguez - srodrig2@uach.cl; Carlos R Yulis - cyulis@uach.cl; Cristian Oliver - coliver@uach.cl; Esteban M Rodríguez* - erodrigu@uach.cl

* Corresponding author

Published: 24 January 2008

Cerebrospinal Fluid Research 2008, 5:3 doi:10.1186/1743-8454-5-3

This article is available from: http://www.cerebrospinalfluidresearch.com/content/5/I/3

(c) 2008 Vio et al; licensee BioMed Central Ltd.

This is an Open Access article distributed under the terms of the Creative Commons Attribution License (http://creativecommons.org/licenses/by/2.0), which permits unrestricted use, distribution, and reproduction in any medium, provided the original work is properly cited.
Received: 3 October 2007

Accepted: 24 January 2008

\begin{abstract}
Background: The subcommissural organ (SCO) is a highly conserved brain gland present throughout the vertebrate phylum; it secretes glycoproteins into the cerebrospinal fluid (CSF), where they aggregate to form Reissner's fiber (RF). SCO-spondin is the major constituent protein of RF. Evidence exists that the SCO also secretes proteins that remain soluble in the CSF. The aims of the present investigation were: (i) to identify and partially characterize the SCO-secretory compounds present in the SCO gland itself and in the RF of the Sprague-Dawley rat and nonhydrocephalic hyh mouse, and in the CSF of rat; (ii) to make a comparative analysis of the proteins present in these three compartments; (iii) to identify the proteins secreted by the SCO into the CSF at different developmental periods.
\end{abstract}

Methods: The proteins of the SCO secreted into the CSF were studied (i) by injecting specific antibodies into ventricular CSF in vivo; (ii) by immunoblots of SCO, RF and CSF samples, using specific antibodies against the SCO secretory proteins (AFRU and anti-PI5). In addition, the glycosylated nature of SCO-compounds was analysed by concanavalin $A$ and wheat germ agglutinin binding. To analyse RF-glycoproteins, RF was extracted from the central canal of juvenile rats and mice; to investigate the CSF-soluble proteins secreted by the SCO, CSF samples were collected from the cisterna magna of rats at different stages of development (from El8 to PN30).

Results: Five glycoproteins were identified in the rat SCO with apparent molecular weights of 630 , $450,390,320$ and $200 \mathrm{kDa}$. With the exception of the $200-\mathrm{kDa}$ compound, all other compounds present in the rat SCO were also present in the mouse SCO. The 630 and $390 \mathrm{kDa}$ compounds of the rat SCO have affinity for concanavalin A but not for wheat germ agglutinin, suggesting that they correspond to precursor forms. Four of the AFRU-immunoreactive compounds present in the SCO $(630,450,390,320 \mathrm{kDa})$ were absent from the RF and CSF. These may be precursor and/or partially processed forms. Two other compounds $(200,63 \mathrm{kDa})$ were present in SCO, RF and CSF and may be processed forms. The presence of these proteins in both, RF and CSF suggests a steadystate RF/CSF equilibrium for these compounds. Eight AFRU-immunoreactive bands were consistently found in CSF samples from rats at EI8, E20 and PNI. Only four of these compounds were detected in the cisternal CSF of PN30 rats. The $200 \mathrm{kDa}$ compound appears to be a key 
compound in rats since it was consistently found in all samples of SCO, RF and embryonic and juvenile CSF.

Conclusion: It is concluded that (i) during the late embryonic life, the rat SCO secretes compounds that remain soluble in the CSF and reach the subarachnoid space; (ii) during postnatal life, there is a reduction in the number and concentration of CSF-soluble proteins secreted by the SCO. The molecular structure and functional significance of these proteins remain to be elucidated. The possibility they are involved in brain development has been discussed.

\section{Background}

The subcommissural organ (SCO) differentiates at an early stage of ontogenetic development in all vertebrates [1] and, with the exception of a few species (anthropoids and bats) [2], it remains fully active throughout life. The secretion of this gland is released into the ventricular cerebrospinal fluid (CSF) where most of it condenses to form a filamentous structure named after Reissner [3] as Reissner's fiber (RF). RF is formed by the assembly of complextype, high molecular weight glycoproteins secreted by the SCO into the cerebral aqueduct; it is a dynamic structure that continuously grows caudally by the addition of newly released molecules to its cephalic end $[2,4]$; it extends throughout the aqueduct of Sylvius, fourth ventricle and central canal of the spinal cord $[4,5]$. When arriving at the terminal ventricle of the central canal at the filum, RF glycoproteins undergo chemical modification, disassembly and passage into neighbouring vessels [6,7]. RF has the capacity to bind and transport away compounds such as dopamine, L-DOPA and serotonin, thus contributing to the clearance of these compounds from the CSF $[8,9]$.

The identification and characterization of the secretory compounds of the SCO have been the subject of numerous investigations and have contributed to partial clarification of its function. Immunoblot analyses of bovine SCO using antibodies against RF glycoproteins have led to the identification of high molecular weight glycoproteins of 540, 450, 320 and $190 \mathrm{kDa}$. Evidence has been obtained indicating that the 540 and the $320 \mathrm{kDa}$ compounds would correspond to precursor forms [10-12]. In the SCO of chick embryos, del Brio et al. have determined the presence of three compounds of 540, 320 and 230 $\mathrm{kDa}$ [13]. In the SCO of the elasmobranch Scyliorhinus canicula, five compounds of 600, 475, 400, 145 and 35 $\mathrm{kDa}$ have been identified [14]. Antibodies raised against the precursor form of $540 \mathrm{kDa}$ and the processed form of $450 \mathrm{kDa}$ synthesized by the bovine SCO, when used to immunostain the bovine and rat $\mathrm{SCO}$, react with the bovine SCO but not with the rat SCO. At variance, the antibody against the bovine SCO $320 \mathrm{kDa}$ band reacts with both, bovine and rat SCO $[11,12]$. This is the only information available concerning the secretory compounds of the SCO of murine species.
Ontogenetic studies have revealed that the SCO starts to express a secretory activity much earlier than the appearance of the first RF $[1,15]$. In the rat, the SCO is well developed and immunoreactive with the anti-RF antibodies at embryonic day 14 (E14). However, aggregated secretory material and a RF proper first appear during the first postnatal week [1]. These findings suggest that the embryonic SCO secretes compounds that remain soluble in the CSF, thus differing from RF proteins, which aggregate. The existence of CSF-soluble compounds secreted by the SCO gained support by immunochemical studies in human and rabbit CSF [2,16]. Recently, Hoyo-Becerra et al. [17] have described the presence in the CSF from chick embryos of proteins that are reactive with anti-RF antiserum (AFRU). Efforts to detect SCO glycoproteins in the bovine CSF have failed $[18,19]$. None of previous studies have dealt with the characterization of the SCO secretory glycoproteins present in the gland itself, in the CSF and in the RF of the same animal species and using immunoblot methodology; this has prevented a comparative analysis of the secretory proteins before they are released and after they either assemble into RF or remain soluble in the CSF. Thus, whether the SCO proteins forming RF and the SCO proteins solubilized in the CSF are the same, or similar or unrelated compounds has yet to be determined.

The primary structure of the major constituent of bovine $\mathrm{RF}$, SCO-spondin, has been fully established as a large $\mathrm{N}$ glycosylated protein $(450 \mathrm{kDa})[20,21]$. Several lines of evidence indicate that SCO-spondin plays a role in CNS development. SCO-spondin belongs to a protein superfamily exhibiting conserved motifs of the thrombospondin type 1 repeat [21]. Proteins of this family are strongly expressed during mammalian CNS development and are involved in mechanisms of cellular adhesion and axonal pathfinding [22]. It has not yet been established whether SCO-spondin itself or its processed products are present in and circulate through the CSF compartments. Neither has it been established whether SCO-spondin or related compounds are actually secreted into the embryonic CSF. This information is essential when interpreting the potential role of SCO-spondin in CNS development.

The present investigation was designed to investigate the rat and mouse SCO glycoproteins in order (i) to identify 
and partially characterize the secretory compounds present in the gland itself, in the RF and in the CSF (rat only); (ii) to make a comparative analysis of the proteins present in these three compartments, in order to establish to what extent they share gel migration, immunoreactive and lectin-binding properties; and (iii) to identify the proteins secreted by the SCO into the CSF at different developmental periods. The identification of the CSF-soluble secretion of the SCO during embryonic and juvenile life may throw some light on the function of this gland. Indeed, such CSF-soluble proteins would circulate throughout both the internal and external CSF compartments and could reach distant targets. Furthermore, differences in the type or concentration of these CSF-soluble proteins at different developmental stages may open new avenues for SCO research.

\section{Methods}

\section{Animals}

Sprague-Dawley rats and $h y h$ mice: Sprague-Dawley rats and $h y h$ mice were obtained from The Jackson Laboratory (Bar Harbor, ME, USA) and bred in two colonies (Facultad de Medicina, Universidad Austral de Chile, Valdivia, Chile). Housing, handling, care and processing of animals were carried out according to the regulations approved by the council of the American Physiological Society. A local university committee has approved the experimental protocol. Animals were fed ad libitum with rodent food and maintained under a constant 12-h light/dark photoperiod and at a constant temperature. Female rats were checked for the presence of a vaginal plug after overnight mating with a male. At days 18,19 and 20 of pregnancy, pregnant rats were weighed and anesthetized with an intraperitoneal injection of ketamine $(40 \mathrm{mg} / \mathrm{kg}$ ) and acepromazine $(100 \mathrm{mg} / \mathrm{kg})$; embryos were removed and CSF was collected from the cisterna magna.

For mice, the hyh mutation arose spontaneously on the C57BL/10J. They were then outcrossed onto a B6C3Fe-a/ a background $(\mathrm{C} 57 \mathrm{BL} / 6 \mathrm{~J} \times \mathrm{C} 3 \mathrm{HeB} / \mathrm{FeJ}-\mathrm{a} / \mathrm{a})$. Hence, the genetic background of $h y h$ mice strain $(\mathrm{B} 6 \mathrm{C} 3 \mathrm{Fe}$ a/aNapahyh/J) is C57BL/6J $\times \mathrm{C} 3 \mathrm{HeB} / \mathrm{FeJ}-\mathrm{a} / \mathrm{a}$. In the present study only non-hydrocephalic mice were used. No differences between wild type and heterozygous mice were detected with the methods used.

\section{Immunocytochemistry}

The brains of 10 Sprague-Dawley rats, PN2, were fixed by intravascular perfusion with Bouin fixative and embedded in paraffin. Sections were processed by the immunoperoxidase method of Sternberger et al. [23]. The following primary antibodies were used: (i) An antiserum developed in rabbits against bovine RF-glycoproteins extracted in a medium containing urea (AFRU, $\mathrm{A}=$ antiserum, $\mathrm{FR}=$ Fiber of Reissner, U = urea; [24]), (ii) An antiserum devel- oped in rabbits against a synthetic 15-aminoacid peptide with a sequence deduced from a region of the SCO-spondin protein that does not correspond to any of the repeats present in this molecule (anti-P15; $[21,25]$ ). This peptide sequence has no homology with any of the proteins recorded in the Gene Bank; hence anti-P15 can be regarded as a specific antibody for SCO-spondin [25]. Sections were sequentially incubated in: (i) AFRU, dilution 1:1000, or anti-P15, dilution 1:500, for $18 \mathrm{~h}$; (ii) secondary antibody (anti-rabbit IgG, raised in our laboratory), diluted 1:15, for 30 min; (iii) rabbit PAP (Dako, Carpinteria, CA, USA), diluted 1:75, for $30 \mathrm{~min}$. All immunocytochemical reactions were visualized by the histochemical detection of peroxidase using hydrogen peroxide (Merck, Darmstadt, Germany) and 3-3'diaminobenzidine tetrahydrochloride (DAB, Sigma, Madrid, Spain). Omission of the incubation in the primary antibody was used as a control.

\section{Injection of antibodies into the rat CSF}

Eight PN2 Sprague-Dawley pups were anesthetized with an intraperitoneal injection of ketamine $(40 \mathrm{mg} / \mathrm{kg})$ and acepromazine $(100 \mathrm{mg} / \mathrm{kg})$; anesthesia lasted throughout the experiment. The head of the pup was immobilized by placing it into a paraffin cast specially adapted to the head of PN2 rats. Using a dissecting microscope, a 27-gauge cannula connected to a perfusion pump, was inserted into the left lateral ventricle; $3 \mu$ l of undiluted AFRU $(n=4)$ or anti-P15 $(n=4)$ sera were infused over $5 \mathrm{~min}$. Two hours after antibody administration, the brain was dissected out and fixed by immersion in Bouin's fixative for $2 \mathrm{~d}$. After dehydration in alcohols, the brains were embedded in paraffin. For the demonstration of binding sites of the injected antibodies, sections were sequentially incubated with anti-rabbit IgG, diluted 1:15, for $30 \mathrm{~min}$, and rabbit PAP (Dako, Carpinteria, CA, USA), diluted 1:75, for 30 min. This was followed by the diaminobenzidine reaction.

\section{Reissner's fiber extracts}

Bovine spinal cord from adult cows was obtained as described previously [24] and RF was collected by perfusing the central canal of the spinal cord with saline. RF of 10 juvenile rats (PN30) and 8 juvenile mice (PN30) was collected in the following way: after euthanasia with ketamine, the spinal cord was dissected out, immersed in buffered saline and divided into several segments by making transverse cuts with a razor blade. Under a dissecting microscope, a cylinder of the grey matter surrounding the central canal was obtained by doing four longitudinal cuts; this block of tissue contained the central canal and the corresponding stretch of RF. The bovine and murine RFs were extracted in $50 \mathrm{mM}$ ammonium bicarbonate, $\mathrm{pH}$ 7,4, containing $0.5 \mathrm{mM}$ phenyl-methylsulfonyl fluoride (PMSF). The protein concentration of bovine RF extract 
[26] was $0.8 \mu \mathrm{g} / \mu \mathrm{l}$, rat central canal/RF extracts ranged from $8.0-8.6 \mu \mathrm{g} / \mu \mathrm{l}$ and mouse central canal/RF extracts ranged from $5.0-6.4 \mu \mathrm{g} / \mu \mathrm{l}$. Samples were stored at $-70^{\circ} \mathrm{C}$ until used.

\section{SCO extracts}

Fifty PN30 rats and thirty PN30 mice were used. The animals were sacrificed under ketamine anesthesia, the brain was dissected out and a block of tissue containing the SCO and the posterior commissure was obtained under a dissecting microscope; post-mortem interval was 2-5 min. Six SCOs were pooled to make one sample. Each sample was extracted in $300 \mu \mathrm{l}$ of $50 \mathrm{mM}$ ammonium bicarbonate, $\mathrm{pH}$ 7,5, and 0,5 mM phenyl-methylsulfonyl fluoride (PMSF), homogenized, sonicated in ice for $10 \mathrm{~s}$ and centrifuged at $12.000 \mathrm{~g}$, for $45 \mathrm{~min}$, at $4{ }^{\circ} \mathrm{C}$. Three aliquots of $100 \mu \mathrm{l}$, each containing the equivalent of two SCOs, were obtained from each extracted sample. Protein content of rat SCO extracts ranged from 1.5 to $2.2 \mu \mathrm{g} / \mu \mathrm{l}$ and of mouse SCO extracts from $1.2-1.3 \mu \mathrm{g} / \mu \mathrm{l}$. Extracts were stored at $-70^{\circ} \mathrm{C}$. The bovine SCO of adult animals was collected and extracted (protein concentration 1.2 $1.35 \mu \mathrm{g} / \mu \mathrm{l})$ as previously reported [12].

\section{Cerebrospinal fluid collection}

Rats: E18 $(n=18), \mathrm{E} 19(n=22)$ and E20 $(n=20)$ rat embryos were used for CSF collection. CSF samples were obtained through a 30-gauge needle inserted into the cisterna magna. About 10-15 $\mu \mathrm{l}$ were obtained from each embryo. Pups at PN1 $(n=12)$ and PN7 $(n=20)$ were anesthetized with ketamine $(40 \mathrm{mg} / \mathrm{kg})$ and acepromazine $(100 \mathrm{mg} / \mathrm{kg})$, the head flexed and a 27 -gauge needle inserted into the cisterna magna. In PN30 rats $(n=22)$ CSF was collected from the cisterna magna according to Rodríguez et al. [9]. Occasionally, severence of a blood vessel caused contamination of the samples with blood and these samples were discarded. About 25-50 $\mu$ l of CSF were obtained from each pup and up to $100 \mu \mathrm{l}$ from each PN30 rat. CSF samples were collected into Eppendorf tubes and centrifuged twice to remove cells or cell debris. Average protein concentrations of E18, E20, PN1, PN7 and PN30 CSF samples were: $2.4,1.8,1.5,1.0$ and $0.4 \mu \mathrm{g} /$ $\mu \mathrm{l}$, respectively. Samples were stored at $-70^{\circ} \mathrm{C}$.

\section{Immunoblot analyses}

The following samples were used for blotting: (i) $50 \mu \mathrm{l}$ samples of SCO extracts, containing the equivalent of 0.02 bovine SCO, 1 mouse SCO and 1 rat SCO; (ii) $50 \mu \mathrm{l}$ samples of RF extracts containing the equivalent of 0.001 bovine RF, 0.1 mouse RF and 0.1 rat RF; (iii) $15 \mu$ l of undiluted/non concentrated CSF from embryonic and postnatal rats. Samples were subjected to SDS-PAGE using a 5$15 \%$ polyacrylamide linear gradient. Proteins were transferred to nitrocellulose membranes [27]; to block nonspecific binding, blots were saturated with 5\% non-fat milk in $0.1 \mathrm{M}$ PBS containing $0.15 \mathrm{mM} \mathrm{NaCl}$ and $0.1 \%$ Tween-20 (Sigma, Madrid, Spain), for $90 \mathrm{~min}$. Two primary antisera were used for immunoreaction of blots of SCO and RF: (i) AFRU, 1:25,000 dilution, for $2 \mathrm{~h}$; (ii) antiP15 [24], 1:1,000 dilution, for 2 h. Anti-rabbit IgG-HRP (Pierce, Rockford, IL, USA) was used at 1:25,000 dilution, for $1.5 \mathrm{~h}$. For immunoblotting of CSF samples, the following protocol was used: (i) AFRU, at 1:5,000 dilution and anti-rabbit IgG-HRP at 1:25,000 dilution, for $2 \mathrm{~h}$; (ii) antiP15, at 1:1,000 dilution and anti-rabbit IgG-HRP at 1:60,000 dilution, for $2 \mathrm{~h}$. Incubations were at room temperature and in darkness. Immunoreactive polypeptides were detected by using an enhanced chemiluminescence (ECL) system (Super Signal, Pierce, Rockford, IL, USA) as instructed by the manufacturer. Molecular weight standards in the range of 10-250 kDa were used (Bio-Rad, Hercules, CA, USA). Control blots were processed as above without the primary antibody. Immunoblotting of samples was repeated as follows: SCO of rat and mouse $\times 10$; RF of rat and mouse $\times 5$; rat CSF of E18 and E20 embryos $\times 5$; rat CSF collected at PN1, PN7 and PN30 × 10. Immunoblots were digitized ( $n=4$ for each condition analysed) and linear densitograms were obtained using the UN SCAN-IT software (Silk Scientific, Orem, UT, USA). Statistical analyses were performed using the Prism software (GraphPad Software, San Diego, CA, USA) applying the 1way Anova and Tukey's test.

\section{Lectin binding}

Blots of bovine, rat and mouse SCO in parallel to those used for immunoblotting, were used to test for lectin binding. Blots were sequentially incubated with (i) oxidized bovine serum albumin (BSA, Winkler, Santiago, Chile), (ii) concanavalin A (Con A; affinity = mannose, glucose; Sigma, St. Louis, MO, USA), $0.2 \mu \mathrm{g} / \mathrm{ml}$ for $1 \mathrm{~h}$; (iii) anti-Con A developed in rabbits (Sigma, St. Louis, MO, USA), 1:10,000 dilution for $1 \mathrm{~h}$ at room temperature; (iii) anti-rabbit IgG-HRP (Pierce, Rockford, IL, USA) $1: 25,000$, for $1.5 \mathrm{~h}$; (iv) binding was detected by using an enhanced chemiluminescence system (see above). The same protocol was used for binding of wheat germ agglutinin (WGA; affinity = glucosamine, sialic acid, Sigma, St. Louis, MO, USA). WGA was used at a concentration of 0.5 $\mu \mathrm{g} / \mathrm{ml}$ and anti-WGA (Sigma, St. Louis, MO, USA) was used at a 1:5,000 dilution.

Con A has affinity for internal, and preferentially for terminal, mannose residues; this makes it a good marker for newly synthesised glycoproteins that have not yet been processed through the Golgi apparatus (precursor forms). At variance, WGA has affinity for two sugar residues (glucosamine, sialic acid) added to the glycoprotein by the Golgi apparatus, thus being a good marker of post-Golgi compounds (processed forms) [28,29]. 


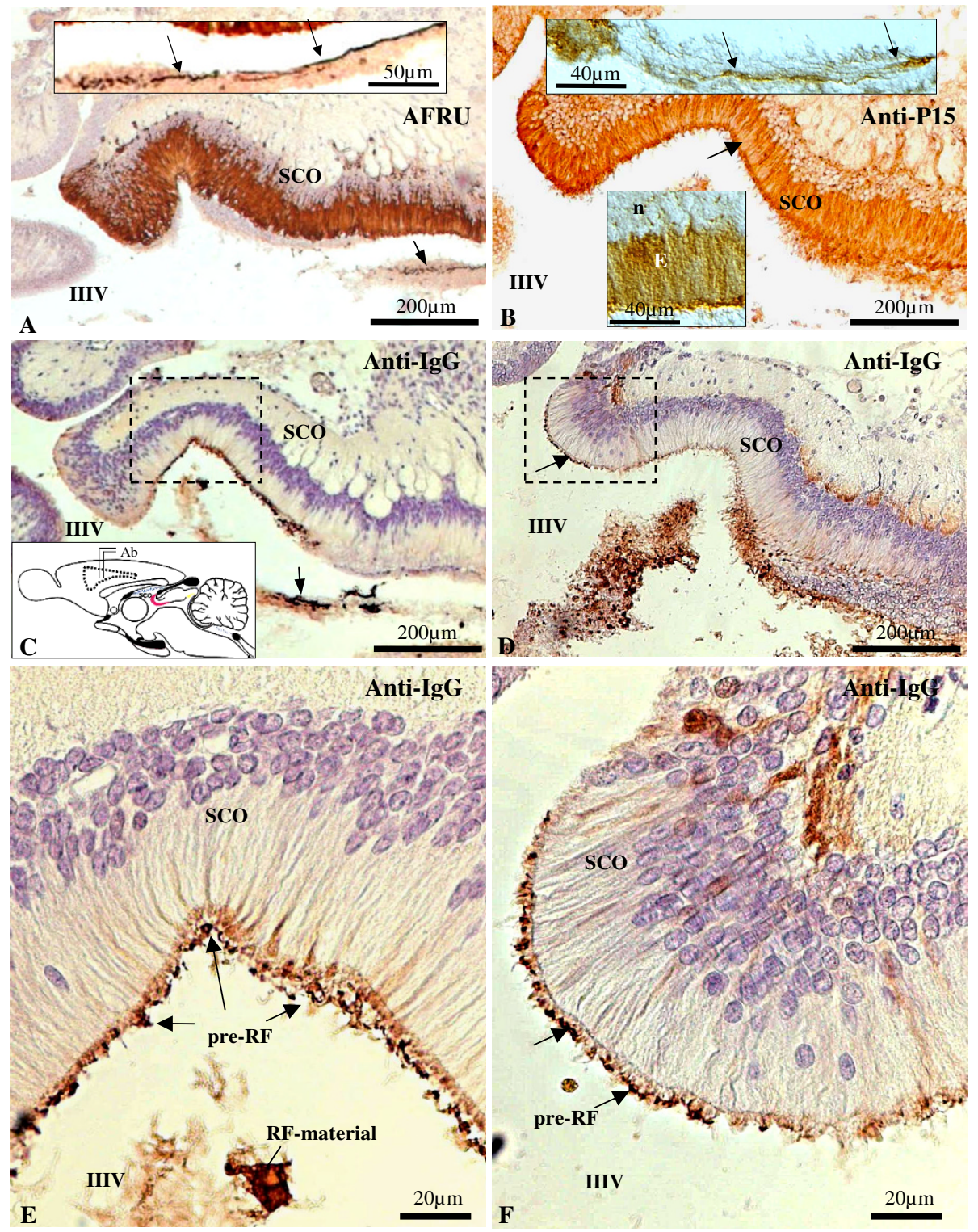

Figure I

A, C, E: Paraffin sagittal sections through the subcommissural organ (SCO) of a PN2 rat after a single injection of AFRU into a lateral ventricle (inset IC, labeled Ab). A: Immunostaining using AFRU (raised in rabbits) as primary antibody. The SCO is immunoreactive. Arrow points to RF-material. Insert: Detailed magnification of RF fibrils immunoreactive with AFRU (arrows). C: Adjacent section to that shown in A, immunostained using anti-rabbit IgG as primary antibody to reveal the antibody (AFRU) administered in vivo. The latter appears exclusively bound to the newly released secretory material aggregated on the surface of the SCO to form the pre-RF (square) and to aggregated RF-material lying in the ventricle (arrow). E: Detailed magnification of area framed in $C$ showing the location of the antigen-antibody complexes formed in vivo at the pre-RF layer on the SCO surface and at the aggregated RF-material. B, D, F: Paraffin sagittal sections through the SCO of a PN2 rat after a single injection of anti-PI5 into a lateral ventricle. B: Sagittal section through the SCO immunostained with anti-PI5. The ependymal cells of the SCO appear immunostained (arrow). Lower insert: detailed magnification of the secretory ependyma (E) showing the location of the immunoreactive material in the supranuclear cytoplasm. n: nuclei. Upper insert: detailed magnification of RF fibrils immunoreactive with anti-PI5 (arrows). D: Section immunostained with anti-rabbit IgG as primary antibody to reveal the location of the antibody administered in vivo at pre-RF (arrow). F: Detailed magnification of area framed in previous figure showing the location of the antigen-antibody complexes formed in vivo at the pre-RF (arrows). IIIV: third ventricle. Most sections counterstained with hematoxilin. 


\section{Results Immunocytochemistry}

The compounds secreted by rat SCO were identified using two antibodies. One is directed against bovine RF constitutive proteins (AFRU), whilst anti-P15 is directed against a 15-aminoacid sequence of SCO-spondin, the main constitutive protein of RF. Both antibodies are highly specific for the rat SCO secretion, located either intracellularly or extracellularly in the form of aggregated RF-material (Fig. $1 \mathrm{~A}, \mathrm{~B}, 2)$. The SCO-specificity of AFRU and anti-P15 is also evident when used in vivo. After the intraventricular administration of these antibodies, they bound exclusively to the SCO secretory material that had been released into the ventricle and that had aggregated into the form of pre-RF or RF [4] (Fig. 1C-F, 2A).

\section{Analysis of rat and mouse SCOextracts}

The secretory compounds of the SCO of PN30 rats and mice were analysed in parallel with the well known secretory glycoproteins of the bovine SCO $[11,12]$. Despite the small size of the rat and mouse SCO, the use of a high-sensitivity Western blot system based on enhanced chemiluminescence enabled demonstration of the secretory compounds using samples containing the equivalent of one SCO. As reported previously [12], the Western blot analysis of the bovine SCO, using AFRU as primary antibody, revealed polypeptides of 540, 450, and $320 \mathrm{kDa}$ (Fig. 2C). The high sensitivity of the method used in the present study, allowed detection of an additional immunoreactive band of $390 \mathrm{kDa}$ (Fig. 2C). The rat and mouse SCO displayed a pattern of AFRU-immunoreactive bands that differed from that of the bovine SCO (Fig. 2C). The $540-\mathrm{kDa}$ polypeptide present in the bovine SCO was not detected in rat and mouse SCO (Fig. 2C). The rat SCO displayed AFRU-immunoreactive bands of 630, 450, 390, 320 and $200 \mathrm{kDa}$ (Fig. 2C, Tables 1, 2). In a few blots, bands of 63 and $45 \mathrm{kDa}$ were also detected (Figs. 2D, 3A, Tables 2, 3). The compounds of 630 and $200 \mathrm{kDa}$ were absent from the bovine SCO.

With the exception of the 200-kDa compound, all high molecular mass compounds present in the rat SCO were also present in the mouse SCO (Fig. 2C).

\section{Analysis of central canal/Reissner's fiber extracts}

Immunoblotting of a tissue extract that included the central canal of the spinal cord and RF of mice and rats at PN30, revealed AFRU-immunoreactive bands most likely corresponding to RF-glycoproteins. In the rat RF, compounds of 200, 120 and $45 \mathrm{kDa}$ were detected in all blots (Fig. 2D, Tables 2, 3). Compounds of 63, 50 and $25 \mathrm{kDa}$ were detected in 2 or 3 of the 5 blots (Tables 2, 3). In the mouse RF the 200-kDa compound was detected in all blots; compounds of 63 and $45 \mathrm{kDa}$ were present in most blots; a polypeptide of $120 \mathrm{kDa}$ was never detected (Fig. 2D).

\section{Analysis of CSF samples}

In order to identify those compounds secreted by the SCO into the CSF and that, at variance with RF-glycoproteins, remain soluble in the CSF, samples of this fluid were obtained from embryo, early postnatal and juvenile rats and analysed by immunoblotting using AFRU and antiP15.

CSF samples collected from the cisterna magna during the late embryonic life (E18, E19, E20) and the early postnatal life (PN1, PN7) displayed a very similar pattern of AFRU-immunoreactive bands (Fig. 2E). The latter were of 200, 180, 164, 145, 120, 63, 50 and $25 \mathrm{kDa}$ (Fig. 2E, Table $2,3)$. This band pattern was found in all blots. There were, however, some differences of intensity of immunoreaction among bands of samples collected at different ages (E18 to PN7; Fig. 2E, F). The 50 and $25 \mathrm{kDa}$ compounds were more strongly reactive in fetal CSF, whilst the 200 and $120 \mathrm{kDa}$ polypeptides were more reactive in PN1 and PN7 samples (Fig. 2E, F).

A marked difference was observed in the cisternal CSF obtained from PN30 rats; the following bands present in previous stages were absent: $180,164,145(P<0.05)$ and $120 \mathrm{kDa}(P<0.001)$ and only bands for $200,63,50$, and $25 \mathrm{kDa}$ were seen (Fig. 2E, F, Table 2, 3).

\section{Comparative analysis of immunoreactive secretory proteins in the rat SCO, RF and CSF}

The high sensitivity of the Western blot system has enabled for the first time within the same species, detection of the AFRU-immunoreactive polypeptides present in the SCO, RF and CSF. This, in turn, has made possible the following comparative analysis: (i) the four AFRU-immunoreactive compounds with the largest molecular mass (630, $450,390,320 \mathrm{kDa}$ ) were present in the SCO and missing from RF and CSF (Table 2, 3). These were possibly precursor or partially processed forms. (ii) Two other compounds $(200,63 \mathrm{kDa})$ were present in SCO, RF and CSF (Tables 2, 3), possibly processed forms; (iii) three compounds $(200,120,63 \mathrm{kDa})$ were present in RF and CSF (Table 2) and possibly in a steady-state equilibrium; (iv) CSF of rat embryos had five bands $(180,164,145,50,25$ $\mathrm{kDa}$ ) not detected in the rat SCO or RF at PN30 (Table 2, compare Figs. 2D and 2E); (v) CSF of PN30 rats had two bands $(50,25 \mathrm{kDa})$ not detected in the rat SCO and inconsistently detected in RF at PN30 (Table 2). The 200$\mathrm{kDa}$ compound was consistently found in all blots of SCO, RF and CSF from rats (Table 2). 

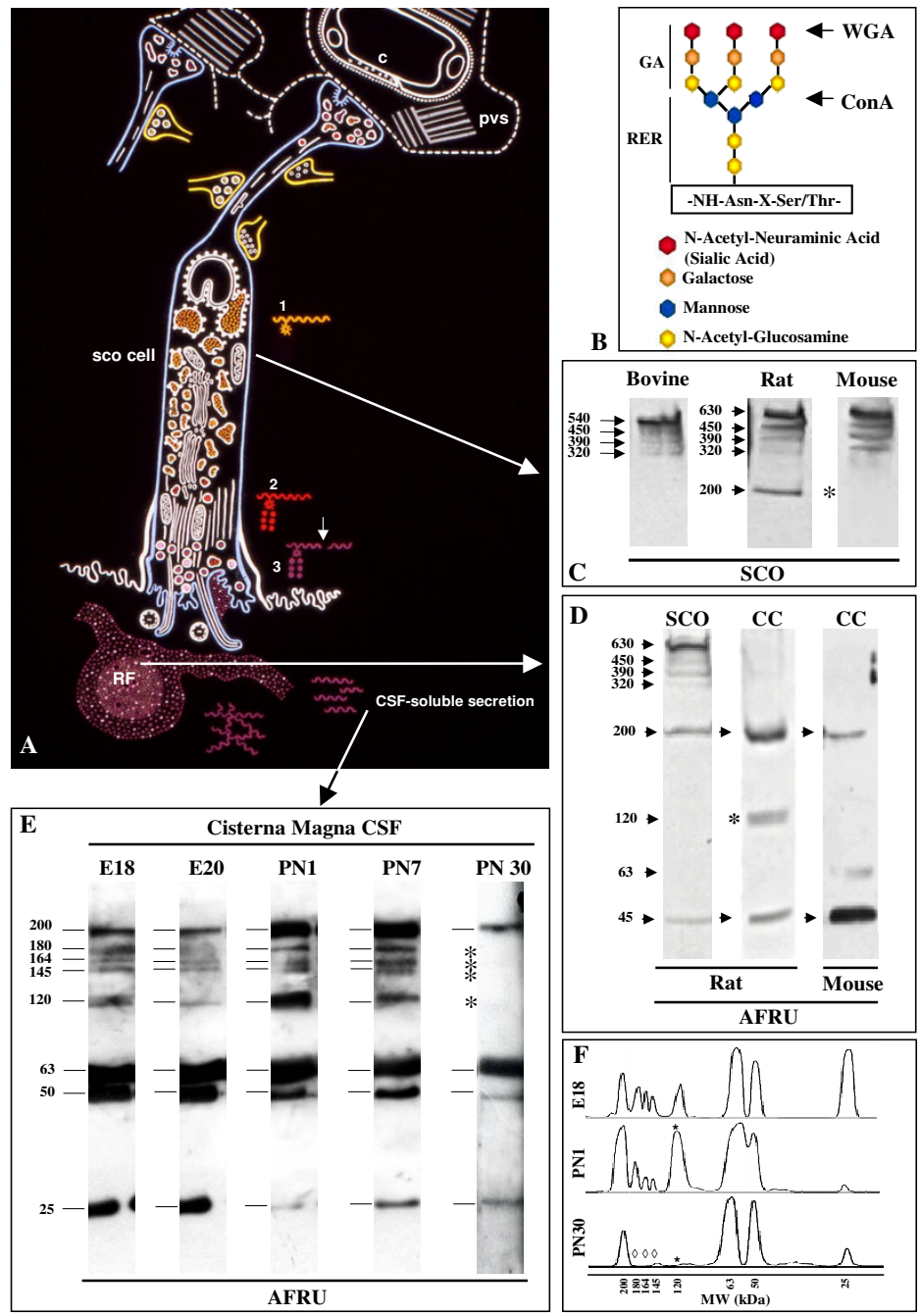

Figure 2

A: Schematic representation of a secretory ependymal cell of the rat SCO. In the rough endoplasmic reticulum secretory proteins have $\mathrm{N}$-linked, high mannose type oligosaccharides (I). In the Golgi cisternae glucosamine, galactose and sialic acid are conjugated to the saccharide core (2). In the secretory granules and in the released secretion, the backbone protein of the secretory glycoproteins undergoes cleavage $(3$, arrow) $[12,28]$. The secretory glycoproteins released into the ventricle may become densely packed forming Reissner's fiber (RF) or may remains soluble in the cerebrospinal fluid (from Rodriguez et al. [16]). B: Schematic representation of a $\mathrm{N}$-linked, complex type, oligosaccharide. The core of glucosamine and mannose are conjugated in the rough endoplasmic reticulum (RER); glucosamine, galactose and sialic acid are conjugated in the Golgi apparatus (GA). Concanavalin A (Con A) has affinity for internal and terminal mannose residues; wheat germ agglutinin (WGA) has affinity for terminal residues of glucosamine and sialic acid. C: Immunoblotting analysis of the subcommissural organ (SCO) using AFRU as primary antibody. Four immunoreactive polypeptides are detected in the adult bovine SCO, five in the PN30 rat SCO and four in the PN30 mouse SCO. Numbers: refer to molecular weight in kDa; arrows: secretory compounds; asterisk indicates the absence of $200 \mathrm{kDa}$ compound. D: Immunoblotting analyses using AFRU as primary antibody of extracts of rat SCO and rat and mouse central canal (CC) at PN30. Numbers refer to molecular weight in kDa. Two polypeptides of 200 and $45 \mathrm{kDa}$ were present in all samples. Asterisk: immunoreactive band of $120 \mathrm{kDa}$ present only in the rat central canal. E: Western blot analysis of cisternal CSF collected from EI8, E20, PNI, PN 7 and PN30 rats. Numbers refer to molecular weight in kDa. Eight immunoreactive polypeptides are detected in the CSF collected perinatally (EI8, E20, PNI, PN7) (horizontal lines). Four of these compounds are missing from the CSF of PN30 rats (asterisks). F: Densitometric linear scannings of CSF immunoblots at EI8, PNI and PN30. The statistical analysis using four immunoblots each revealed a significant difference in luminescence value of the $120 \mathrm{kDa}$ band between EI 8 and PNI (*, $P<0.00 \mathrm{I})$, and between PNI and PN30 $(P<0.00 \mathrm{I})$. Differences between EI8 and PN30 in the I80, 164 and I45 kDa bands were also significant $(\& \# \times 25 C A ; P<0.05)$. 
Table I: Immunoreactivity to AFRU and lectin binding of proteins extracted from the bovine, rat and mouse subcommissural organ

\begin{tabular}{|c|c|c|c|c|c|c|c|c|c|}
\hline \multirow[t]{2}{*}{ MW } & \multicolumn{3}{|c|}{ *Bovine SCO (adult) } & \multicolumn{3}{|c|}{ Rat SCO (PN30) } & \multicolumn{3}{|c|}{ Mouse SCO (PN30) } \\
\hline & AFRU & Con A & WGA & AFRU & Con A & WGA & AFRU & Con A & WGA \\
\hline 630 & & & & + & + & - & + & + & - \\
\hline 540 & + & + & - & & & & & & \\
\hline 450 & + & + & + & + & + & + & + & + & + \\
\hline 390 & + & + & & + & + & - & + & + & - \\
\hline 320 & + & + & - & + & + & + & + & + & + \\
\hline 200 & & & & + & + & + & & & \\
\hline
\end{tabular}

MW, molecular weights in kilo Daltons; SCO, subcommissural organ; AFRU, antibody against all glycoproteins of bovine RF; Con A, concanavalin A (affinity = mannose, glucose); WGA, wheat germ agglutinin (affinity = glucosamine, sialic acid); +, positive reaction; -, negative reaction. *From Nualart et al. 199| [12].

Table 2: Comparative analysis of AFRU-immunoreactive proteins extracted from the rat subcommissural organ, Reissner's fiber and from the cisterna magna CSF

\begin{tabular}{|c|c|c|c|c|c|c|}
\hline \multirow[t]{2}{*}{ MW } & \multicolumn{3}{|c|}{ SCO (PN30) } & \multirow{2}{*}{$\begin{array}{c}\text { RF (PN30) } \\
\text { AFRU }\end{array}$} & \multirow{2}{*}{$\begin{array}{c}\text { CSF (EI8-PN7) } \\
\text { AFRU }\end{array}$} & \multirow{2}{*}{$\begin{array}{c}\text { CSF (PN30) } \\
\text { AFRU }\end{array}$} \\
\hline & AFRU & ConA & WGA & & & \\
\hline 630 & + & + & - & & & \\
\hline 450 & + & + & + & & & \\
\hline 390 & + & + & - & & & \\
\hline 320 & + & + & + & & & \\
\hline 200 & + & + & + & + & + & + \\
\hline 180 & & & & & + & \\
\hline 164 & & & & & + & \\
\hline 145 & & & & & + & \\
\hline 120 & & & & + & + & \\
\hline 63 & $*$ & & & $*$ & + & + \\
\hline 50 & & & & $*$ & + & + \\
\hline 45 & $*$ & & & + & & \\
\hline 25 & & & & * & + & + \\
\hline
\end{tabular}

MW, molecular weights in kilodaltons; SCO, subcommissural organ; RF, Reissner's fiber; AFRU, antibody against all glycoproteins of bovine RF; Con $\mathrm{A}$, concanavalin $\mathrm{A}$ (affinity = mannose, glucose); WGA, wheat germ agglutinin (affinity = glucosamine, sialic acid); +, positive reaction consistently present in all samples; *, positive reaction only found in some samples. Two upper boxes indicate putative precursor forms only present in SCO. Lower box indicates the only compound consistently found in SCO, RF and CSF (processed form).

\section{Comparison of immunoblot analysis of SCO, RF and CSF using AFRU and anti-PI 5}

Blots of rat SCO run in parallel and immunoreacted with AFRU and anti-P15 showed: (i) out of the four compounds of large molecular weight revealed by AFRU, only the $320 \mathrm{kDa}$ reacted with anti-P15 (Fig. 3A, Table 3); (ii) the bands of 63 and $45 \mathrm{kDa}$ reacted with both antibodies (Fig. 3A, Table 3); (iii) bands of 80, 37 and $32 \mathrm{kDa}$ only reacted with anti-P15 (Fig. 3A, Table 3).

Blots of rat RF run in parallel and immunoreacted with AFRU and anti-P15 showed: (i) both antibodies reacted with the 200, 120 and $45 \mathrm{kDa}$ compounds (Table 3); (ii) bands of 320,164, 145, 80 and $32 \mathrm{kDa}$ only reacted with anti-P15 (Table 3).

Blots of CSF of E18, E20 and PN7 rats run in parallel and immunoreacted with AFRU and anti-P15 showed: (i) out of the eight bands revealed by AFRU (200 to $25 \mathrm{kDa}$ ), only the 200, 180, 145 and $63 \mathrm{kDa}$ reacted with anti-P15 (Fig. 3B, Table 3).

Evidence for the existence of two precursor forms of the secretory proteins in the rat and mouse SCO

Proteins extracted from the rat, mouse and bovine SCO were blotted and run in parallel for immunoreaction with AFRU and Con A and WGA binding (Fig. 2B, 4; Table 1). In bovine SCO, four bands that immunoreacted with AFRU (540, 450, 390 and $320 \mathrm{kDa}$ ) bound Con A (Fig. $4 \mathrm{~A}$, Table 1). The five polypeptides detected with AFRU in the rat SCO $(630,450,390,320,200 \mathrm{kDa})$ bound Con A, but only the compounds of 450, 320 and $200 \mathrm{kDa}$ bound WGA (Fig. 4B, Table 1).

The four polypeptides detected with AFRU in the mouse SCO $(630,450,390,320 \mathrm{kDa})$ were Con A-positive (Fig. 
4C); only the 450 and $320 \mathrm{kDa}$ compounds bound WGA (Fig. 4C, Table 1).

\section{Discussion \\ Identification of the precursor and processed forms of the glycoproteins secreted by the rat and mouse SCO}

Reissner's fiber results from the assembly of large molecular weight proteins released by the SCO into the CSF circulating through the cerebral aqueduct. The major constituent protein of RF is SCO-spondin. The aminoacid sequence of bovine SCO-spondin has been fully established by Meiniel [21]. In the bovine SCO, three major compounds of 540, 450 and $320 \mathrm{kDa}$, reacting with an antiserum raised against the constitutive proteins of RF (AFRU), have been described [12]. Due to the lectin binding properties and the subcellular localization of these three compounds, Nualart et al. [25] have selected a 15aminoacid sequence from a region of SCO-spondin that was used to raise antibodies in rabbits. This antibody (anti-P15) specifically reacts with the bovine and rat SCO and RF and can be regarded as a specific marker of SCOspondin [25]. In immunoblots of bovine SCO, anti-P15 reacts with the 540 and $450 \mathrm{kDa}$ bands, indicating that both bands correspond to SCO-spondin, with the former being the precursor and the latter a processed form. The molecular weight deduced from the aminoacid sequence of bovine SCO-spondin is $540 \mathrm{kDa}$ [30]. The nature of the $320 \mathrm{kDa}$ protein has yet to be investigated.

In the rat and mouse SCO, the $540 \mathrm{kDa}$ compound was absent; instead an AFRU-immunoreactive compound of $630 \mathrm{kDa}$ was seen. This compound has immunoreactive and lectin-binding properties similar to the bovine 540 $\mathrm{kDa}$ SCO-spondin, indicating that it corresponds to a murine SCO-spondin. The sequence of the mouse SCOspondin contains 4981 aminoacids with a theoretical protein mass of $535 \mathrm{kDa}$. When compared to the bovine SCO-spondin there is a $66.8 \%$ homology [30].

Considering the large number of cryptic sites of N-glycosylaton present in the sequence of SCO-spondin, the larger molecular mass of rat and mouse SCO-spondin could be due to a higher degree of glycosylation.

According to the lectin binding properties of all AFRUimmunoreactive glycoproteins present in the rat and mouse SCO (Table 1), the 630 and $390 \mathrm{kDa}$ compounds would correspond to precursor forms present in the rough endoplasmic reticulum of the SCO secretory cells. Indeed, they bound Con A, a lectin with affinity for mannose residues added to the nascent protein in the rough endoplasmic reticulum, but did not bind WGA, a lectin specific for two sugar residues (glucosamine, sialic acid) added to the glycoprotein by the Golgi apparatus $[2,4]$. At variance, the 450, 320 and $200 \mathrm{kDa}$ proteins did bind WGA, indicating that they are post-Golgi compounds located, most likely, in the secretory granules. The presence of the $200 \mathrm{kDa}$ glycoprotein in RF is strongly supportive of the suggestion that this compound corresponds to a processed form.

Out of the four compounds of large molecular weight revealed by AFRU in the rat SCO, only the $320 \mathrm{kDa}$ reacted with anti-P15 (Table 3 ). Since this antibody is specific for SCO-spondin, it may be postulated that the 320 $\mathrm{kDa}$ protein corresponds to SCO-spondin. However, antiP15 did not reveal the $630 \mathrm{kDa}$ compound that most likely corresponds to the precursor of the rat SCO-spondin. A likely explanation for this result is that anti-P15, reacting with a 15 -aminoacid sequence of a protein that consists of about 4,500 amino acids, might not have access to its epitopes when rat SCO-spondin is in its precursor form.

Out of the eight bands consistently revealed by AFRU in the embryonic CSF, only four of them $(200,180,145,63$ $\mathrm{kDa})$ reacted with anti-P15. This suggests that the latter compounds would be derived from the SCO-spondin precursor (630 kDa) and the AFRU-positive, anti-P15-negative compounds derived from the second putative precursor (390 kDa).

\section{Are CSF-soluble compounds secreted by the SCO intracellularly processed and released into CSF, or "released" from RF?}

The $200 \mathrm{kDa}$ appears as a key protein, since it was present in the SCO, RF and embryonic and juvenile CSF of rats, and immunoreacted with AFRU and anti-P15. This indicates that this protein is a processed form of SCOspondin released by the SCO cells into the CSF. In the rat, the $200 \mathrm{kDa}$ compound represented the major constituent protein of RF. A steady-state RF/CSF equilibrium for this protein might explain the permanent presence of this compound in both, RF and CSF. On the other hand, the presence of the $200 \mathrm{kDa}$ protein in the embryonic CSF, before the first RF has formed, and in the juvenile cisternal $\mathrm{CSF}$, a compartment where RF is absent, indicates that this protein is secreted as a CSF-soluble protein and remains soluble in the circulating CSF.

The $63 \mathrm{kDa}$ protein detected in all CSF samples and in some samples of SCO and RF, might also be regarded as a processed form secreted by the SCO to form RF as well as to be CSF-soluble.

The two proteins of 180 and $164 \mathrm{kDa}$, found in the embryonic CSF but absent from the juvenile SCO, CSF and RF, would correspond to processed forms released by the SCO during late embryonic life. Since immunoblot analysis of the embryonic SCO has not been performed, the possibility that these compounds were derived from a 
Table 3: Immunoreactivity to AFRU and anti-PI 5 of proteins extracted from the rat subcommissural organ, Riessner's fiber and cisterna magna CSF

\begin{tabular}{|c|c|c|c|c|c|c|}
\hline \multirow[t]{2}{*}{ MW } & \multicolumn{2}{|c|}{ SCO (PN30) } & \multicolumn{2}{|c|}{ RF (PN30) } & \multicolumn{2}{|c|}{ CSF (E I 8-PN7) } \\
\hline & AFRU & Anti-P I 5 & AFRU & Anti-P I 5 & AFRU & Anti-P I 5 \\
\hline 630 & + & & & & & \\
\hline 450 & + & & & & & \\
\hline 390 & + & & & & & \\
\hline 320 & + & + & & + & & \\
\hline 200 & + & & + & + & + & + \\
\hline 180 & & & & & + & + \\
\hline 164 & & & & + & + & \\
\hline 145 & & & & + & + & + \\
\hline 120 & & & + & + & + & \\
\hline 80 & & + & & + & & \\
\hline 63 & $*$ & $*$ & $*$ & $*$ & + & $*$ \\
\hline 50 & & $*$ & $*$ & & + & \\
\hline 45 & $*$ & $*$ & + & + & & \\
\hline 37 & & + & & & & \\
\hline 32 & & + & & + & & \\
\hline 25 & & & $*$ & & + & \\
\hline
\end{tabular}

MW, molecular weights in kilodaltons; SCO, subcommissural organ; RF, Reissner's fiber; AFRU, antibody against all glycoproteins of bovine RF; anti$\mathrm{PI}$, antibody specific for SCO-spondin; +, positive reaction consistently present in all samples; *, positive reaction only found in some samples. Horizontal box indicates $200 \mathrm{kDa}$ compound consistently found in all samples. The eight AFRU-immunoreactive compounds detected in embryonic CSF were consistently found in all samples; only three of them react with anti-PI5.

source other than the SCO has to be considered. Indeed, from E15 to PN1 the rat floor plate, that extends along the ventral midline of the spinal cord and hindbrain, secretes proteins immunoreactive with AFRU [31]. Although floor plate explants release these proteins to culture medium [32], there is no evidence that they are actually released into the embryonic CSF.

There were AFRU and anti-P15 immunoreactive proteins present in the rat RF and/or juvenile CSF $(120,50,25$ $\mathrm{kDa}$ ) that were absent from the SCO. Since these compounds were consistently detected in all blots, it seems unlikely they result from artefactual degradation of larger proteins during handling and processing of the samples. The possibility that these proteins result from a postrelease cleavage of compounds secreted by the SCO into the CSF has to be considered and investigated. A similar phenomenon has been described in bovines, where several AFRU-immunoreactive polypeptides forming RF are not present in the SCO $[11,12,33]$. The possibility of a post-release processing of high molecular mass glycoproteins released into the CSF of chick embryos has been suggested [17]. In the bovine, the wall of the central canal, especially at the lumbo-sacral level, contains AFRU-reactive cells [34]. These cells have not been detected in the rat and mouse central canal. However, considering that in the present investigation, rat RF was extracted together with the wall of the central canal, the possibility should be considered that AFRU-immunoreactive proteins present in the central canal/RF extract but absent in the SCO extract, may have originated from cells lining the central canal.

\section{The CSF-soluble compounds secreted by the rat SCO} circulate in the internal and external CSF compartments

After the intraventricular injection of an antibody against RF-proteins, such an antibody immunoreacts with the proteins newly released by the SCO, forming insoluble antigen-antibody complexes on the surface of this gland that were detected by immunocytochemistry using antiIgG as primary antibody [35]. The same procedure has been used in the present investigation. AFRU and anti-P15 injected into the ventricular CSF formed insoluble antigen-antibody complexes exclusively located on the surface of the SCO, indicating that the rat SCO does secrete AFRU and anti-P15 reactive compounds into the third ventricle. Since AFRU and anti-P15 reactive compounds are also present in the cisternal CSF (see above), it may be concluded that the CSF-soluble proteins secreted by the SCO into the third ventricle circulate through the aqueduct of Sylvius, fourth ventricle and subarachnoid space.

\section{In the fetal CSF the number and concentration of SCO} secretory products is higher than in the CSF of juvenile rats The developing CNS of various vertebrate species has been investigated using methods to visualize RF-proteins. Two structures, the floor plate and the SCO, have been shown to share the property to synthesize RF-like material $[36,37]$. The use of anti-RF sera has confirmed that both structures secrete proteins reacting with these antibodies $[31,37,38]$. It has also been shown that both, the floor 
A

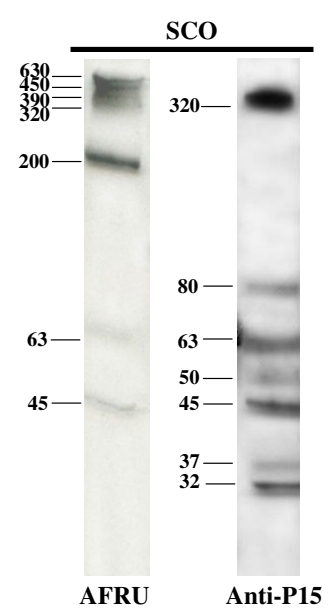

B

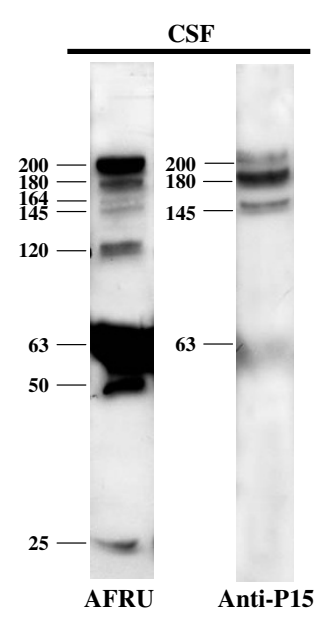

Figure 3

Immunoblots of rat SCO at PN30 (panel A) and cisternal CSF at PN7 (panel B), using AFRU and anti-PI5 as primary antibodies. The four AFRU-immunoreactive compounds with the largest molecular mass $(630,450,390,320 \mathrm{kDa})$ are present in the SCO and missing from the CSF. Two other compounds $(200,63 \mathrm{kDa})$ are present in the SCO and CSF (processed forms?). The CSF has four bands (I80, I64, I45, 120 $\mathrm{kDa})$ not seen in the SCO. The SCO has only one large molecular mass compound reacting with anti-PI 5 (specific for SCO-spondin) and several bands of lower molecular masses. The CSF compounds of 200, 180, 145 and $63 \mathrm{kDa}$, reacting with both antibodies are most likely to be SCOspondin derivatives.

plate and SCO of bovine embryos, express the SCO-spondin gene and synthesize the $540 \mathrm{kDa}$ protein [39]. The rat floor plate synthesizes AFRU-immunoreactive proteins from E15 to PN1, with the highest activity around E18 [31]. In vitro studies have shown that the bovine floor plate cells release AFRU-reactive proteins of 540 and 60 $\mathrm{kDa}$ into the culture medium [32]. The rat SCO starts to secrete AFRU-reactive material at E14; by E18 it is fully developed and displaying a high secretory activity [1]. Since RF starts to form at PN1, and a RF proper is first seen in the central canal at PN7, it has been assumed that the compounds secreted by the fetal SCO remain soluble in the CSF [1].

In the present investigation, eight AFRU-immunoreactive compounds were consistently found in all CSF samples collected from E18 to PN1. Only four of these compounds $(200,63,50,25 \mathrm{kDa})$ were also detected in the CSF of juvenile rats. It may be assumed that the source of these proteins is the SCO since in the juvenile rat this gland is the only brain structure secreting AFRU-reactive proteins. On the other hand, the four AFRU-immunoreactive pro-

teins present only in the CSF collected from E18 to PN1 could be secreted by the SCO, the floor plate or by both glands. Five AFRU-immunoreactive proteins have been shown to occur in the CSF of chick embryos [17]. The authors obtained evidence to suggest that in chick embryos, these proteins may be derived from both the SCO and floor plate.

\section{Functional significance of the existence of CSF-soluble proteins secreted by the SCO}

The embryonic CSF may be regarded as the main component of the milieu of stem cells and progenitor cells of the germinal zone [40]. In rat embryos, the flowing CSF is in permanent and direct contact with the ventricular and subventricular zones and, after E17, it reaches the subarachnoid space to bathe the marginal zone of the brain cortex [41]. The CSF is an efficient route to convey signals between different regions of the brain $[41,42]$. In the adult rat, tracers injected into the ventricles move freely into the brain parenchyma through the ependymal lining [43-45]; similarly, tracers injected into the subarachnoid space enter the brain parenchyma through the pial surface [44,46-48]. However, the functional relationship between the ventricular and subrachnoid compartments and the parenchyma of the embryonic brain is not clear. There is a significant body of evidence indicating that CSF carries vital signal molecules to the germinal epithelium of the developing brain cortex $[41,49,50]$. CSF from rat embryos, used as culture medium, has the capacity to sustain the proliferative activity of the embryonic cerebral cortex [51]. Rat CSF collected at E19 has the highest capacity to induce neuronal proliferation, compared to CSF obtained at other developmental periods, indicating that the CSF composition changes during development [51]. Rat CSF promotes the neuronal differentiation from neurospheres obtained from stem cells of the subventricular zone of the lateral ventricle [52]. Several factors known to participate in brain development have been detected in the embryonic CSF, namely, fibroblast growth factor (FGF2), epidermal growth factor (EGF), transforming growth factor TGF-b), neural growth factor (NGF), brainderived growth factor (BDGF), transthyretin [53-62]. The source of most of these signals in not known.

The eight AFRU-immunoreactive compounds detected in the CSF of rat embryos (present report), especially those that also react with anti-P15 (a SCO-spondin marker), are good candidates to participate in brain development. This possibility is supported by previous observations. The immunological blockage of the SCO during development by maternal transfer of antibodies leads to brain abnormalities [63]. There is strong evidence indicating that SCO-spondin promotes neuronal growth and differentiation [64]. The fact that the eight AFRU-immunoreactive compounds have been detected in the cisterna magna CSF 

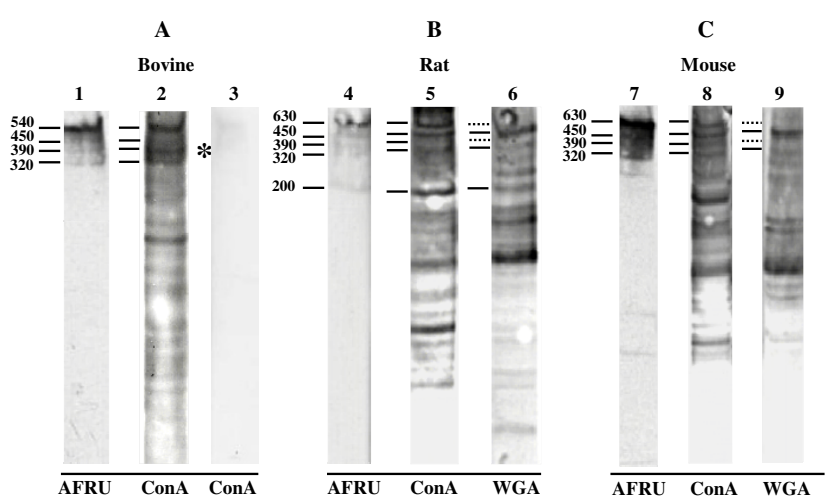

Figure 4

Immunoblots of SCO extracts of bovine (adult, lanes I-3), rat (PN30, lanes 4-6) and mouse (PN30, lanes 7-9). Lanes I, 4, 7: immunoblots using AFRU. Lanes 2, 5, 8: concanavalin A (Con A) binding. Lanes 6, 9: wheat germ agglutinin (WGA) binding. Lane 3: concanavalin A blocked with mannose prior to binding. No binding is detected (asterisk). Numbers: molecular weight in kDa. Dotted lines: compounds not binding WGA.

indicates they follow the flow of the subarachnoidal CSF and may gain access to the marginal zone of the developing brain cortex. Worth mentioning is the fact that F-spondin, secreted by the floor plate, SCO-spondin secreted by the SCO and reelin, secreted by the Cajal-Retzius cells of the developing cortex, display regions of similarities in their aminoacid sequences and all of them are glycoproteins secreted into the extracellular space $[21,65]$.

The four AFRU-immunoreactive compounds that continue to be present in the CSF of juvenile rats may also be involved in neurogenesis, specially that occurring in the subventricular zone of the lateral ventricle. Transplantation of SCO explants to a lateral ventricle of juvenile rats stimulates neuroblast proliferation and migration [66].

\section{Conclusion}

The present investigation has shown that (i) during late embryonic life, the SCO secretes compounds that remain soluble in the CSF and reach the subarachnoid space; (ii) during postnatal life, there is a reduction in the number and concentration of CSF-soluble proteins secreted by the SCO. The molecular structure and functional significance of these proteins remain to be elucidated. A glycoprotein of $200 \mathrm{kDa}$, found in all rat samples, may be a key compound for SCO function.

\section{Competing interests}

The author(s) declare that they have no competing interests.

\section{Authors' contributions}

$\mathrm{KV}$ and ER initiated and designed the study. KV, SR, CY and ER analysed and interpreted all the data. KV and CO collected data or carried out experiments for the study. KV and ER contributed to the preparation of the m.s. All authors have read and approved the final version of the manuscript.

\section{Acknowledgements}

Supported by Grants from Fondecyt 1030265 and 107024I, Chile to EMR and from Universidad Austral de Chile DID S-2006-72 to KV.

\section{References}

I. Schoebitz K, Rodriguez EM, Garrido O, Del Brio Leon MA: Ontogenetic development of the subcommissural organ with reference to the flexural organ. In The Subcommissural Organ An Ependymal Brain Gland Edited by: Oksche A, Rodriguez EM, Fernandez-Llebrez P. Berlin, Heidelberg, New York: Springer; 1993:4I-49.

2. Rodriguez EM, Oksche A, Montecinos $\mathrm{H}$ : Human subcommissural organ, with particular emphasis on its secretory activity during the fetal life. Microsc Res Tech 200I, 52:573-590.

3. Reissner E: Beiträge zur Kenntnis vom Bau des Rüchenmarks von Petromyzon fluviatilis L. Arch anat physiol I860, 77:545-588.

4. Rodriguez EM, Oksche A, Hein S, Yulis CR: Cell biology of the subcommissural organ. Int Rev Cytol 1992, I35:39-I2I.

5. Rodriguez EM, Rodriguez S, Hein S: The subcommissural organ. Microsc Res Tech 1998, 41 :98-123.

6. Peruzzo B, Rodriguez S, Delannoy L, Hein S, Rodriguez EM, Oksche A: Ultrastructural immunocytochemical study of the massa caudalis of the subcommissural organ-Reissner's fiber complex in lamprey larvae (Geotria australis): evidence for a terminal vascular route of secretory material. Cell Tissue Res 1987, 247:367-376.

7. Rodriguez S, Rodriguez PA, Bance P, Rodriguez EM, Oksche A: Reissner's fiber, massa caudalis and ampulla caudalis in the spinal cord of lamprey larvae (Geotria australis). Light-microscopic immunocytochemical and lectin-histochemical studies. Cell Tissue Res 1987, 247:359-366.

8. Caprile T, Hein S, Rodriguez S, Montecinos H, Rodriguez E: Reissner fiber binds and transports away monoamines present in the cerebrospinal fluid. Brain Res Mol Brain Res 2003, I I 0: I 77-I 92.

9. Rodriguez S, Vio K, Wagner C, Barria M, Navarrete EH, Ramirez VD, Perez-Figares JM, Rodriguez EM: Changes in the cerebrospinalfluid monoamines in rats with an immunoneutralization of the subcommissural organ-Reissner's fiber complex by maternal delivery of antibodies. Exp Brain Res 1999, I 28:278-290.

10. Hein S, Nualart F, Rodriguez EM, Oksche A: Partial characterization of the secretory products of the subcommisural organ. In The Subcommissural Organ An Ependymal Brain Gland Edited by: Oksche A, Rodriguez EM, Fernandez-Llebrez P. Berlin, Heidelberg, New York: Springer; 1993:78-88.

II. Nualart F, Hein S: Biosynthesis and molecular biology of the secretory proteins of the subcommissural organ. Microsc Res Tech 200I, 52:468-483.

12. Nualart F, Hein S, Rodriguez EM, Oksche A: Identification and partial characterization of the secretory glycoproteins of the bovine subcommissural organ-Reissner's fiber complex. Evidence for the existence of two precursor forms. Brain Res Mol Brain Res 1991, I I:227-238.

13. del Brio MA, Riera P, Munoz RI, Montecinos H, Rodriguez EM: The metencephalic floor plate of chick embryos expresses two secretory glycoproteins homologous with the two glycoproteins secreted by the subcommissural organ. Histochem Cell Biol 2000, I I 3:4 I 5-426.

14. Lopez-Avalos MD, Perez J, Perez-Figares JM, Peruzzo B, Grondona JM, Rodriguez EM: Secretory glycoproteins of the subcommissural organ of the dogfish (Scyliorhinus canicula): evidence for the existence of precursor and processed forms. Cell Tissue Res 1996, 283:75-84.

15. Schoebitz K, Garrido O, Heinrichs M, Speer L, Rodriguez EM: Ontogenetical development of the chick and duck subcom- 
missural organ. An immunocytochemical study. Histochemistry 1986, 84:3I-40

16. Rodriguez EM, Jara $\mathrm{P}$, Richter $\mathrm{H}$, Montecinos $\mathrm{H}$, Flandes $\mathrm{B}$, Wiegand $R$, Oksche A: Evidence for the release of CSF-soluble secretory material from the subcommissural organ, with particular reference to the situation in the human. In The Subcommissural Organ An Ependymal Brain Gland Edited by: Oksche A, Rodriguez EM, Fernandez-Llebrez P. Berlin, Heidelberg, New York: Springer; | 993:|2|-|3|.

17. Hoyo-Becerra C, Lopez-Avalos MD, Perez J, Miranda E, Rojas-Rios P, Fernandez-Llebrez P, Grondona JM: Continuous delivery of a monoclonal antibody against Reissner's fiber into CSF reveals CSF-soluble material immunorelated to the subcommissural organ in early chick embryos. Cell Tissue Res 2006, 326:77I-786.

18. Estivill-Torrus G, Cifuentes M, Grondona JM, Miranda E, BermudezSilva FJ, Fernandez-Llebrez P, Perez J: Quantification of the secretory glycoproteins of the subcommissural organ by a sensitive sandwich ELISA with a polyclonal antibody and a set of monoclonal antibodies against the bovine Reissner's fiber. Cell Tissue Res 1998, 294:407-4I3.

19. Fernandez-Llebrez P, Miranda E, Estivill-Torrus G, Cifuentes M, Grondona JM, Lopez-Avalos MD, Perez-Martin M, Perez J: Analysis and quantification of the secretory products of the subcommissural organ by use of monoclonal antibodies. Microsc Res Tech 2001, 52:510-519.

20. Gobron S, Creveaux I, Meiniel R, Didier R, Herbet A, Bamdad M, EI Bitar F, Dastugue B, Meiniel A: Subcommissural organ/Reissner's fiber complex: characterization of SCO-spondin, a glycoprotein with potent activity on neurite outgrowth. Glia 2000, 32:|77-19|.

21. Meiniel A: SCO-spondin, a glycoprotein of the subcommissural organ/Reissner's fiber complex: evidence of a potent activity on neuronal development in primary cell cultures. Microsc Res Tech 200I, 52:484-495.

22. Adams JC, Tucker RP: The thrombospondin type I repeat (TSR) superfamily: diverse proteins with related roles in neuronal development. Dev Dyn 2000, 2 1 8:280-299.

23. Sternberger LA, Hardy PH Jr, Cuculis JJ, Meyer HG: The unlabeled antibody enzyme method of immunohistochemistry: preparation and properties of soluble antigen-antibody complex (horseradish peroxidase-antihorseradish peroxidase) and its use in identification of spirochetes. J Histochem Cytochem 1970, 18:315-333.

24. Rodriguez EM, Oksche A, Hein S, Rodriguez S, Yulis R: Comparative immunocytochemical study of the subcommissural organ. Cell Tissue Res 1984, 237:427-44I.

25. Nualart F, Hein S, Yulis CR, Zarraga AM, Araya A, Rodriguez EM: Partial sequencing of Reissner's fiber glycoprotein I (RF-Gly I). Cell Tissue Res 1998, 292:239-250.

26. Bradford MM: A rapid and sensitive method for the quantitation of microgram quantities of protein utilizing the principle of protein-dye binding. Anal Biochem 1976, 72:248-254

27. Towbin H, Staehelin T, Gordon J: Electrophoretic transfer of proteins from polyacrylamide gels to nitrocellulose sheets: procedure and some applications. Proc Natl Acad Sci USA 1979, 76:4350-4354

28. Herrera H, Rodriguez EM: Secretory glycoproteins of the rat subcommissural organ are $\mathrm{N}$-linked complex-type glycoproteins. Demonstration by combined use of lectins and specific glycosidases, and by the administration of Tunicamycin. Histochemistry 1990, 93:607-6I5.

29. Peruzzo B, Rodriguez EM: Light and electron microscopical demonstration of concanavalin $A$ and wheat-germ agglutinin binding sites by use of antibodies against the lectin or its label (peroxidase). Histochemistry 1989, 92:505-513.

30. Goncalves-Mendes N, Simon-Chazottes D, Creveaux I, Meiniel A, Guenet JL, Meiniel R: Mouse SCO-spondin, a gene of the thrombospondin type I repeat (TSR) superfamily expressed in the brain. Gene 2003, 3/ 2:263-270.

31. Rodriguez EM, del Brio Leon MA, Riera P, Menendez J, Schoebitz K The floor plate of the hindbrain is a highly specialized gland. Immunocytochemical and ultrastructural characteristics. Brain Res Dev Brain Res 1996, 97:153-168.
32. Guinazu MF, Richter HG, Rodriguez EM: Bovine floor plate explants secrete SCO-spondin. Cell Tissue Res 2002, 308:|77-|9|

33. Meiniel A, Meiniel R, Didier R, Creveaux I, Gobron S, Monnerie H, Dastugue $B$ : The subcommissural organ and Reissner's fiber complex. An enigma in the central nervous system? Prog Histochem Cytochem 1996, 30: I-66.

34. Rodriguez S, Hein S, Yulis R, Delannoy L, Siegmund I, Rodriguez E: Reissner's fiber and the wall of the central canal in the lumbo-sacral region of the bovine spinal cord. Comparative immunocytochemical and ultrastructural study. Cell Tissue Res 1985, 240:649-662

35. Rodriguez S, Rodriguez EM, Jara P, Peruzzo B, Oksche A: Single injection into the cerebrospinal fluid of antibodies against the secretory material of the subcommissural organ reversibly blocks formation of Reissner's fiber: immunocytochemical investigations in the rat. Exp Brain Res 1990, 81: I I3- I 24.

36. Olsson R: Reissner's fiber mechanisms: some common denominators. In The Subcommissural Organ An Ependymal Brain Gland Edited by: Oksche A, Rodriguez EM, Fernandez-Llebrez P. Berlin, Heidelberg, New York: Springer; 1993:33-39.

37. Yulis CR, Mota MD, Andrades JA, Rodriguez S, Peruzzo B, Mancera JM, Ramirez P, Garrido M, Perez-Figarez JM, Fernandez-Llebrez P, Rodriguez EM: Floor plate and the subcommissural organ are the source of secretory compounds of related nature: comparative immunocytochemical study. J Comp Neurol 1998, 392:19-34.

38. Rodriguez EM, Garrido O, Oksche A: Lectin histochemistry of the human fetal subcommissural organ. Cell Tissue Res 1990, 262:105-113

39. Richter HG, Munoz RI, Millan CS, Guinazu MF, Yulis CR, Rodriguez EM: The floor plate cells from bovines express the mRNA encoding for SCO-spondin and its translation products. Brain Res Mol Brain Res 200I, 93:137-I47.

40. Owen-Lynch PJ, Draper CE, Mashayekhi F, Bannister CM, Miyan JA: Defective cell cycle control underlies abnormal cortical development in the hydrocephalic Texas rat. Brain 2003, | 26:623-63|.

4I. Miyan JA, Nabiyouni M, Zendah M: Development of the brain: a vital role for cerebrospinal fluid. Can J Physiol Pharmacol 2003 , 81:317-328.

42. Rodriguez EM: The cerebrospinal fluid as a pathway in neuroendocrine integration. J Endocrinol 1976, 7 I:407-443.

43. Brightman MW: The distribution within the brain of ferritin injected into cerebrospinal fluid compartments. I. Ependymal distribution. J Cell Biol 1965, 26:99-123.

44. Brightman MW, Reese TS: Junctions between intimately apposed cell membranes in the vertebrate brain. I Cell Biol 1969, 40:648-677.

45. Cifuentes M, Fernandez LP, Perez J, Perez-Figares JM, Rodriguez EM: Distribution of intraventricularly injected horseradish peroxidase in cerebrospinal fluid compartments of the rat spinal cord. Cell Tissue Res 1992, 270:485-494.

46. Brightman MW: The distribution within the brain of ferritin injected into cerebrospinal fluid compartments. II. Parenchymal distribution. Am J Anat 1965, I 17:193-219.

47. Rennels ML, Gregory TF, Blaumanis OR, Fujimoto K, Grady PA: Evidence for a 'paravascular' fluid circulation in the mammalian central nervous system, provided by the rapid distribution of tracer protein throughout the brain from the subarachnoid space. Brain Res 1985, 326:47-63.

48. Pena P, Rodriguez EM, Dellmann HD, Schoebitz K: Effects of colchicine on the hypothalamo-neurohypophysial system of chronically salt-loaded rats. Neuroendocrinology 1988 , 47:217-224.

49. Miyan JA, Mashayekhi F, Bannister CM: Developmental abnormalities in early-onset hydrocephalus: clues to signalling. Symp Soc Exp Biol 2001:91-106.

50. Gato A, Moro JA, Alonso MI, Bueno D, De La Mano A, Martin C: Embryonic cerebrospinal fluid regulates neuroepithelial survival, proliferation, and neurogenesis in chick embryos. Anat Rec A Discov Mol Cell Evol Biol 2005, 284:475-484.

5I. Miyan JA, Zendah M, Mashayekhi F, Owen-Lynch PJ: Cerebrospinal fluid supports viability and proliferation of cortical cells in vitro, mirroring in vivo development. Cerebrospinal Fluid Res 2006, 3:2. 
52. Gonzalez C, Vio K, Muñoz RI, Rodriguez EM: The CSF of normal $\mathrm{H}-\mathrm{Tx}$ rats promotes neuronal differentiation from neurospheres but CSF of hydrocephalic H-Tx rats does not. Cerebrospinal Fluid Res 2006, 3:s I0.

53. Doublier S, Duyckaerts C, Seurin D, Binoux M: Impaired brain development and hydrocephalus in a line of transgenic mice with liver-specific expression of human insulin-like growth factor binding protein-I. Growth Horm IGF Res 2000, 10:267-274.

54. Kasaian MT, Neet KE: Nerve growth factor in human amniotic and cerebrospinal fluid. Biofactors 1989, 2:99-104.

55. Johnson MD, Gold LI, Moses HL: Evidence for transforming growth factor-beta expression in human leptomeningeal cells and transforming growth factor-beta-like activity in human cerebrospinal fluid. Lab Invest 1992, 67:360-368.

56. Mogi M, Harada M, Narabayashi H, Inagaki H, Minami M, Nagatsu $T$ Interleukin (IL)-I beta, IL-2, IL-4, IL-6 and transforming growth factor-alpha levels are elevated in ventricular cerebrospinal fluid in juvenile parkinsonism and Parkinson's disease. Neurosci Lett 1996, 21 1:13-16.

57. Heinze E, Boker M, Blum W, Behnisch W, Schulz A, Urban J, Mauch E: GH, IGF-I, IGFBP-3 and IGFBP-2 in cerebrospinal fluid of infants, during puberty and in adults. Exp Clin Endocrinol Diabetes 1998, 106:197-202.

58. Arnold PM, Ma JY, Citron BA, Festoff BW: Insulin-like growth factor binding proteins in cerebrospinal fluid during human development and aging. Biochem Biophys Res Commun 1999 264:652-656.

59. Johanson CE, Szmydynger-Chodobska J, Chodobski A, Baird A, McMillan P, Stopa EG: Altered formation and bulk absorption of cerebrospinal fluid in FGF-2-induced hydrocephalus. Am J Physiol 1999, 277:R263-27I.

60. Riikonen R, Somer M, Turpeinen U: Low insulin-like growth factor (IGF-I) in the cerebrospinal fluid of children with progressive encephalopathy, hypsarrhythmia, and optic atrophy (PEHO) syndrome and cerebellar degeneration. Epilepsia 1999, 40:1642-1648.

61. Moinuddin SM, Tada T: Study of cerebrospinal fluid flow dynamics in TGF-beta I induced chronic hydrocephalic mice. Neurol Res 2000, 22:215-222.

62. Montecinos HA, Richter H, Caprile T, Rodriguez EM: Synthesis of transthyretin by the ependymal cells of the subcommissural organ. Cell Tissue Res 2005, 320:487-499.

63. Vio K, Rodriguez S, Navarrete EH, Perez-Figares JM, Jimenez AJ, Rodriguez EM: Hydrocephalus induced by immunological blockage of the subcommissural organ-Reissner's fiber (RF) complex by maternal transfer of anti-RF antibodies. Exp Brain Res 2000, 135:41-52.

64. Monnerie H, Dastugue B, Meiniel A: Effect of synthetic peptides derived from SCO-spondin conserved domains on chick cortical and spinal-cord neurons in cell cultures. Cell Tissue Res 1998, 293:407-4|8.

65. Rice DS, Curran T: Role of the reelin signaling pathway in central nervous system development. Annu Rev Neurosci 200I, 24:1005-1039.

66. Gonzalez C: Participación del órgano subcomisural y el líquido cefalorraquídeo en la neurogénesis postnatal. In PhD Thesis Universidad Austral de Chile, Institute of Anatomy, Histology and Pathology, Faculty of Medicine; 2007.
Publish with Bio Med Central and every scientist can read your work free of charge

"BioMed Central will be the most significant development for disseminating the results of biomedical research in our lifetime. "

Sir Paul Nurse, Cancer Research UK

Your research papers will be:

- available free of charge to the entire biomedical community

- peer reviewed and published immediately upon acceptance

- cited in PubMed and archived on PubMed Central

- yours - you keep the copyright
BioMedcentral 